\title{
Management of Municipal Solid Waste in Religious Tourism Park Based on Reduce, Reuse and Recovery: An Indonesian Attraction Case Study
}

\author{
Kasam $^{1, *}$, Fajri Mulya Iresha $^{1}$, and Nino Heri Setyoadi ${ }^{2}$ \\ ${ }^{1}$ Department of Environmental Engineering, Faculty of Civil Engineering and Planning, Universitas \\ Islam Indonesia, Yogyakarta, Indonesia, 55584 \\ ${ }^{2} \mathrm{R} \& \mathrm{D}$ Center for Implementation of Settlement Technology, Ministry Public Works and Human \\ Settlements Republic of Indonesia, Yogyakarta, Indonesia, 55281
}

\begin{abstract}
Solid waste management is a very important part to be done including in the religious tourism park because cleanliness reflect purity. This study aims to plan solid waste management system in the religious tourism park in Indonesia, especially in Gunungpring park tomb. Solid waste management planning is determined by sampling and measuring for eight consecutive days. The solid waste management system is planned to cover storage, collection and transportation as well as processing solid waste facilities named TPS 3R and transportation of the residue. Based on the sampling result and the measurement of solid waste generation, it is known that the average amount of solid waste is about $0.14 \mathrm{~kg}$ or 0.3 liter per person per day. While the composition consists of $49.84 \%, 29.53 \%$ and $20.63 \%$ respectively for recyclable, compostable and disposable waste. Storage at Gunungpring Religious Tourism Park need to be installed in five locations with three types of containers, while collection used motorcycle cart with capacity of 84 liters. In order to obtain optimum results, a planning and designing the TPS $3 \mathrm{R}$ installation is necessary and finally the disposable waste transportation was design to obtain the method and intensity of disposal and size of dump truck.
\end{abstract}

Keywords: Solid waste generation, Religious tourism, Gunungpring park tourism, Solid waste management.

\section{Introduction}

One of the largest tourist destinations in the world is the spiritual tourism park. Indonesia has many spiritual attractions that can be a tourist destination both domestic and foreign tourists. The spiritual destinations of Indonesia, especially in Central Java Province, include: Demak Mosque and Sunan Kalijaga Tomb (Demak Regency), Sunan-Kudus and

* Corresponding author: kasam@uii.ac.id 
Sunan-Muria (Kudus Regency) Tombs, Gunungpring Tombs and Sunan-Geseng Tombs (Magelang Regency). The number of tourist arrivals in Magelang Regency is quite large reaches 4,567,121 people per year mostly visited in the spiritual tourism park [1]. Due to the bumping of population and the living standards, the number of tourist also increase into the level that never be reached before. The presence of tourists will produce solid waste that must be managed properly, so as not to cause negative effects on health and the environment. Therefore, the management of solid waste generation becomes an important factor that must be done. Tourist parks without waste will enhance the good image for tourists [2].

The increasing population and living standards mean that the consumption of goods and energy increases. On the one hand, consumption leads to an increase in waste generation [3]. These things encourages the government and business actors to make solid waste management plans. The management of municipal solid waste (MSW) is a system involving several sub-systems that usually require inputs, materials, and resources that demand to properly process the throughput of solid waste generated. For this reason, MSW management is generally one of the most expensive services provided by the city [4]. However, it is still necessary to fulfill the services because of the negative impacts those can be happen if there are lack of system established.

In solid waste management planning requires reliable data on solid waste generation, factors affecting solid waste generation, and estimated quantity of solid waste based on facts [5]. A comprehensive study of the variables that affect solid waste production and recycling rates is essential to explore the generation mechanism and forecast future household waste dynamics [6]. There are many options to manage solid waste. Currently, solid waste is largely still dispose to landfill, although there are other options for municipal solid waste treatment including waste minimization, material recycling, and energy recovery [7].

On the other hand, there has been a significant increase of MSW in recent decades due to rapid urbanization and industrialization. Due to the lack of source segregation practices, the need for automatic recycling segregation from MSW exists in developing countries [8]. Yet, the automatic recycling segregation need the high technology and high cost. So that, waste segregation still the best option for the developing country, and the system and facility of solid waste management must provide it.

Today is the era of Green Economy and green strategies, such as recycling can provide great benefits to the hotel industry. However, there is a lack of research to support this financial benefit [9]. Currently, 1.3 billion tons of waste is produced annually and this value will increase to about 2.2 billion tons per year by 2025 . The amount of municipal waste can be seen as an opportunity to acquire commodities such as compost, recycled materials, heat or energy [10]. This knowledge of waste composition and generation is important for strategic public policy planning that minimizes its generation and negative environmental impact. However, this MSW portion is not particularly well known [11]. The lack of information, socialization, and regulation make most of people in developing country, especially in Indonesia do not know how to convert the waste into money.

A holistic view and considering the characteristics of different types of waste is required when modeling the reverse supply chain for MSW recycling [12]. The main activity in waste management is waste recovery with special consideration to recycle. The implementation of the recovery process leads to the emergence of a closed material stream where it remains a valuable resource that can be reintroduced into the economy. Unlike recycling, neutralization through landfilling impedes sustainable urban development [13].

There are two main problem of MSW in developing country such as Indonesia. Firstly, urban waste dumps in developing countries consist primarily of degradable materials (> $70 \%$ ), which play an important role in Green House Gas (GHG) emissions in urban areas. 
Increasing urban waste generation along with high fraction organic waste and unscientific waste causes greenhouse gas emissions (methane, $\mathrm{CO}_{2}$, etc.) in the atmosphere [14].

Secondly is recyclable material. Selling recycled materials is an increasingly important component of the retail and trade sectors in general. Due to the economic and environmental benefits of the recycled fraction of MSW, an improvement in MSW's management system infrastructure is required to achieve maximum recycling benefits for this fraction after this important event [15].

Some results show that plastics are the most recyclable waste that is most prevalent in all cities in South-South, South-South and all northern Nigeria. However, paper is the most available recycled material in the flow [16]. Up to now, solid waste generation in Magelang regency including from Gunungpring tourism park, most of it is still dumped into landfills to Pasuruhan landfill. If it methode still continued so the landfill Pasuruhan capacity in three years is immediately full. Therefore, it is necessary to conceptualize waste management in some regions through the reduce, reuse, recovery (3R) concept. This study aims to plan solid waste management system in the religious tourism park in Indonesia, especially in Gunungpring tourism park throught the 3R concep, so result minimizing of waste volume dispose to landfill.

\section{Material and Methods}

The type of planning undertaken is carried out by sampling based on SNI 19-3964-1994 on Methods of Taking and Measuring Sample of Municipal Solid Waste Generation and Composition and American Society for Testing and Matrials (ASTM) Standard Test for Determination of the Composition of Unprocessed Manicipal Solid Waste (ASTM designation D 5231-92) and using quartering method to get waste composition.

\section{Result and Discussion}

\subsection{Profile of Gunungpring Tourism Park}

This research is conducted include waste sampling, determination of garbage characteristic and composition, and waste management planning in Gunungpring Park. It park is located at Jalan Kyai Santri Gunungpring Village, Muntilan District, Magelang Regency, Central Java Province as shown in Figure 1. It is named Gunungpring because located in the middle of the village where there are very lush bamboo tree. Gunungpring park is at an altitude of $400 \mathrm{~m}$ above sea level. Gunungpring religious tourism park is a complex of tombs of the scholar that spread Islam in the Magelang region like Kyai Raden Santri and his descendants. This area is always crowded in the visit pilgrims, especially on Friday night and certain months such as Mulud, Shawwal, Sura, and so forth. The number of visitors in this tourist area around 664 people a day who come from various regions in Indonesia. 


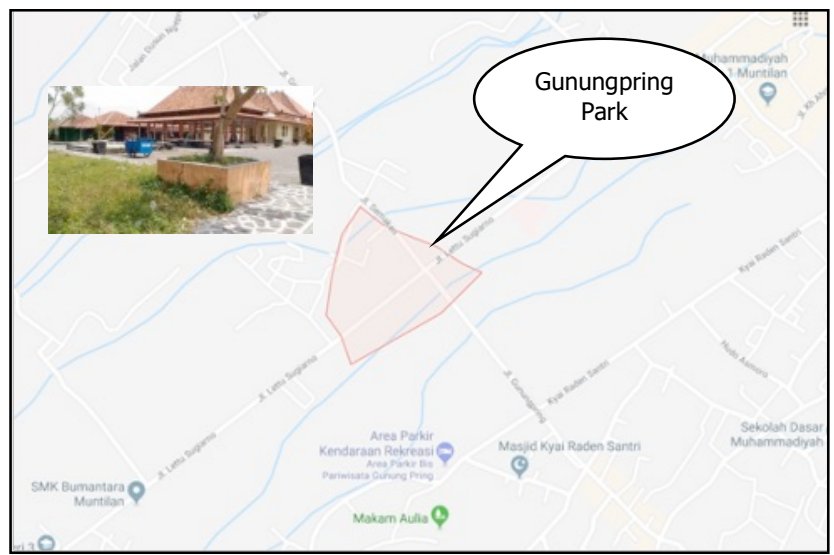

a). Location of Gunungpring Park Tomb

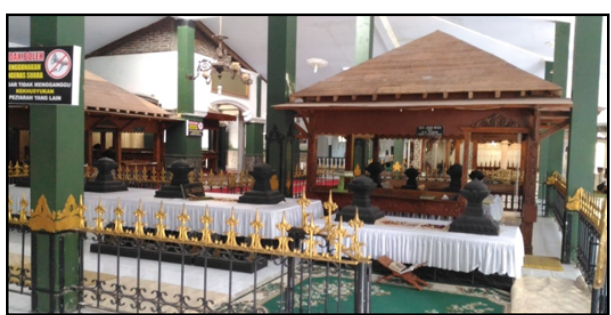

b). Kyai Raden Santri Tomb and His descendants

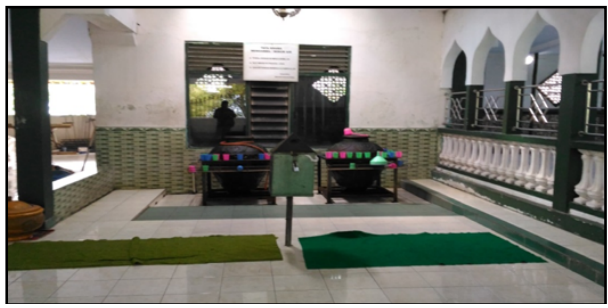

c). Facility for Prayer

Fig. 1. Religious Tourism Park of Gunungpring

\subsection{The Existing of Solid Waste Management}

Solid waste generation in Gunungpring park comes from two locations, namely from the grave area and visitor parking area. The solid waste collected from each container point in source, then taken by officers using the cart collected at the container in transfer station. Waste that have already been in the temporary station dumped by using truck to landfill. The flow of existing solid waste processing in Gunungpring park as shown in Figure 2. Up to now, Magelang district uses landfills which are used as final waste disposal is Pasuruhan landfill. 


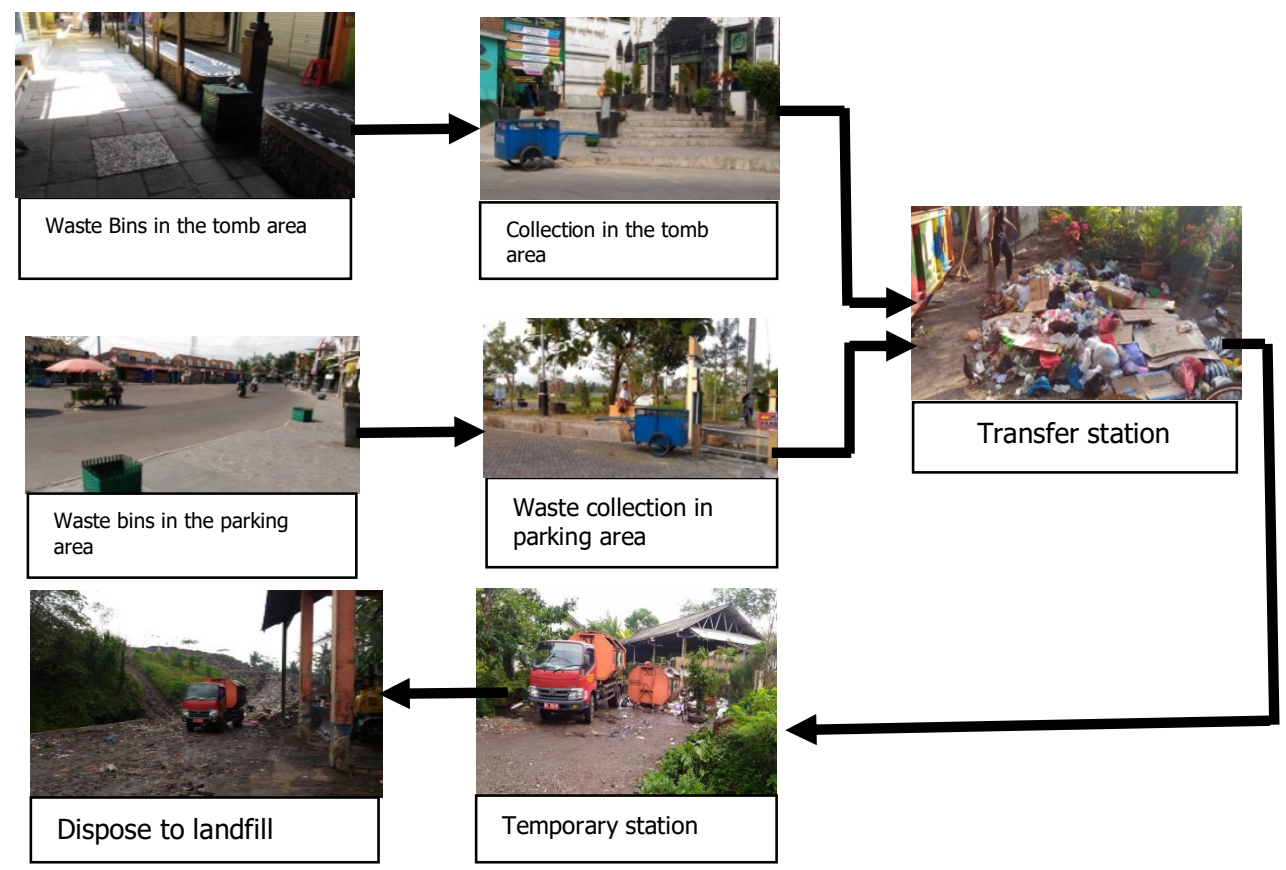

Fig. 2. Scheme of Solid Waste Management in Gunungpring

\subsection{Solid waste generation and it composition}

Based on sampling conducted for eight consecutive days it is known that the solid waste generation in Gunungpring tourism park is directly depend on the number of visitors. The largest number of weeks on Sunday is about $155.1 \mathrm{~kg}$ and the smallest on Wednesday is about $90 \mathrm{~kg}$. Average waste generation per person is $0.14 \mathrm{~kg} /$ visitor / day or 0.3 liter / visitor / day.

Figure $3 \mathrm{a}$, describes the composition of waste generation according to the level of usability consist of recyclable, compostable and disposable of each of 49.84\%, $29.53 \%$ and $20.63 \%$. Components of recyclable consist of plastic (glass, crackle, bottle, bucket), paper (cardboard, color paper, white paper, duplex), metal and glass. While the compostable components include food waste, yard waste and crop residues. Disposable waste includes foodpack cork, tissue, diapers, and wood. In detail on each component as shown in Figure $3 \mathrm{~b}$. Although the amount of waste that is recyclable is $49.84 \%$ and $29.53 \%$ is compostable, yet until now it still canot be realized. This is due to the management system that has not been planned properly from the waste to inadequate processing. 


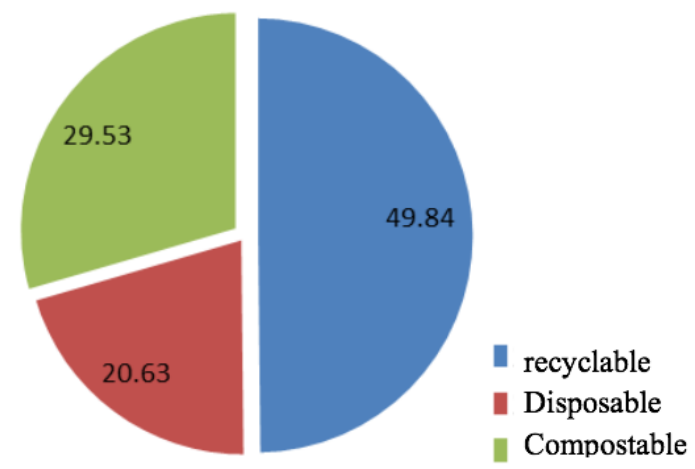

a). Composition (\%) based on sale feasibility
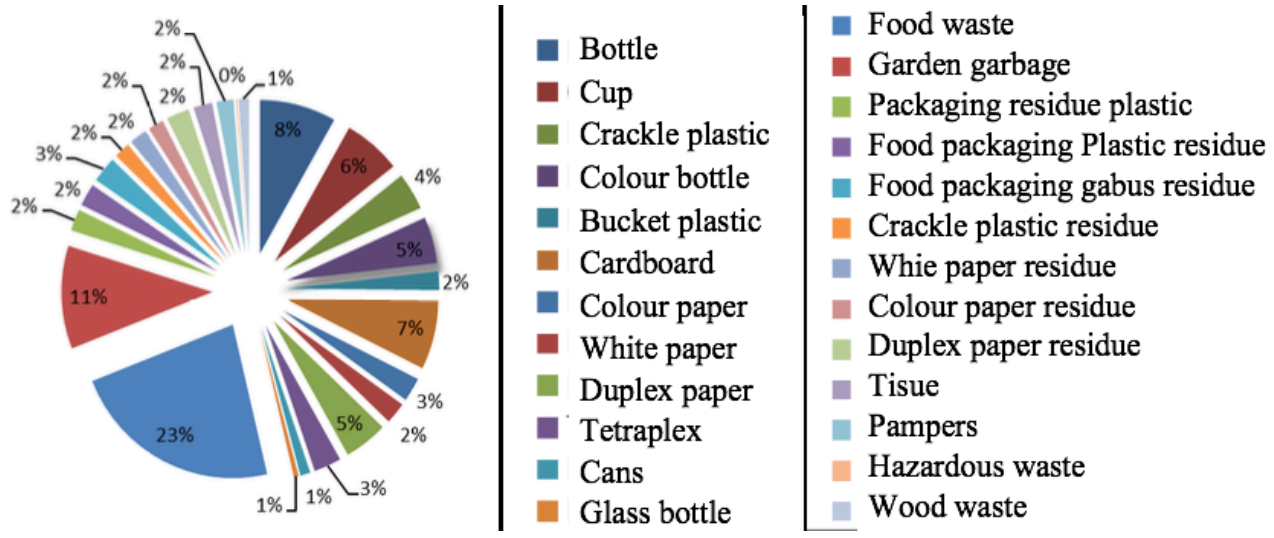

b). Composition (\%) detail each component of Waste

Fig. 3. Composition of Solid Waste Generation in Gunungpring Complex

\subsection{Solid Waste Management Planning}

Waste generation management in Gunungpring park refers to 3R concept (reduce, reuse, recovery). Reduction is the best way to reduce waste generation at source so as to reduce the burden of waste management in the next stage. The second best stage is to reuse (reuse) the waste generation that still allows for re-use, so that it can reduce the waste processing load. The last step in the $3 \mathrm{R}$ concept is recovery is an effort to utilize waste by transforming waste into another useful form. The transformation can be done physically, chemically and biologically to get: improvement of operating efficiency in management system, separation of recycle component and composable component.

Management planning is based on information on the amount of generation and composition, which includes containers, collection, and processing facility plans. The number of visitors is currently about 746 people per day so there is a volume of waste 223.6 liters per day. It is predicted that visitor growth will rise $10 \%$ per year so that in the next 10 years the volume will be 580 liters per day or $104 \mathrm{~kg}$ per day. Peak condition is calculated to reach $100 \%$ or 1160 liters per day. 


\subsection{Storage}

The number of warehouses is planned 5 locations that have three types of separation according to usability that is recyclable, compostable and residual of each volume 200 liters. Various forms of containers that can be used in the Gunungpring tomb complex as shown in Figure 4. In each container it takes religious writing such as "Cleanliness of some faith".

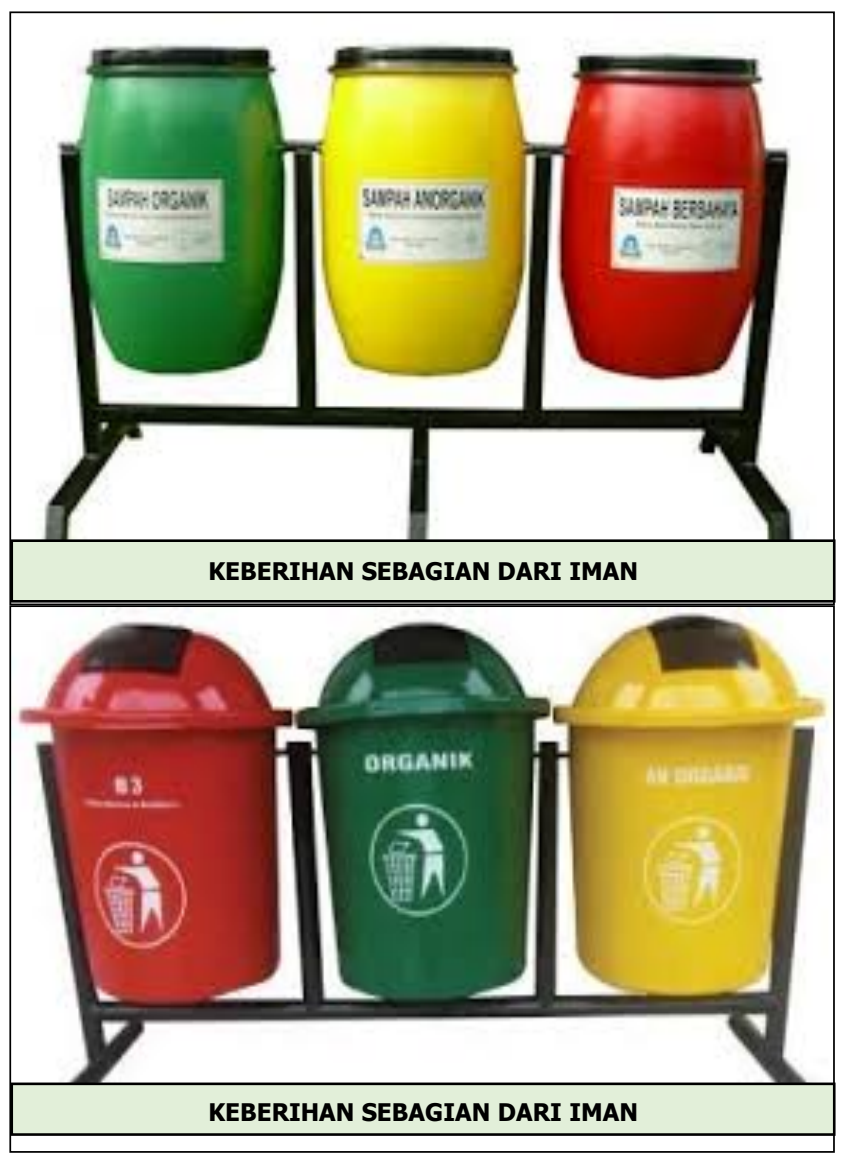

Fig. 4. Examples of Landscapes and Religious Slogans

\subsection{Collecting and Transporting}

Waste collection from each of the locations in the Gunungpring tourism park use manual cart transport because of topography condition which is hill and must use ladder to go to tomb location. With a cart capacity of 840 liters it takes two trips per day. It is then transported to the waste processing installation site.

\subsection{TPS 3R}

The waste processing installation or named as TPS 3R is planned in accordance with SNI 3242-2008 on waste management of settlements. Because the amount of waste originating from Gunungpring Tourism park is only 1160 liters per day then it should be combined 
with the solid waste increment from the people of Gunungpring Village and Pondok Pesantren or Islamic boarding school that is approached around Gunungpring park with population of 1600 and 525 people respectively. The design of 3R TPS instalation in a simple can be seen in figure 5 .

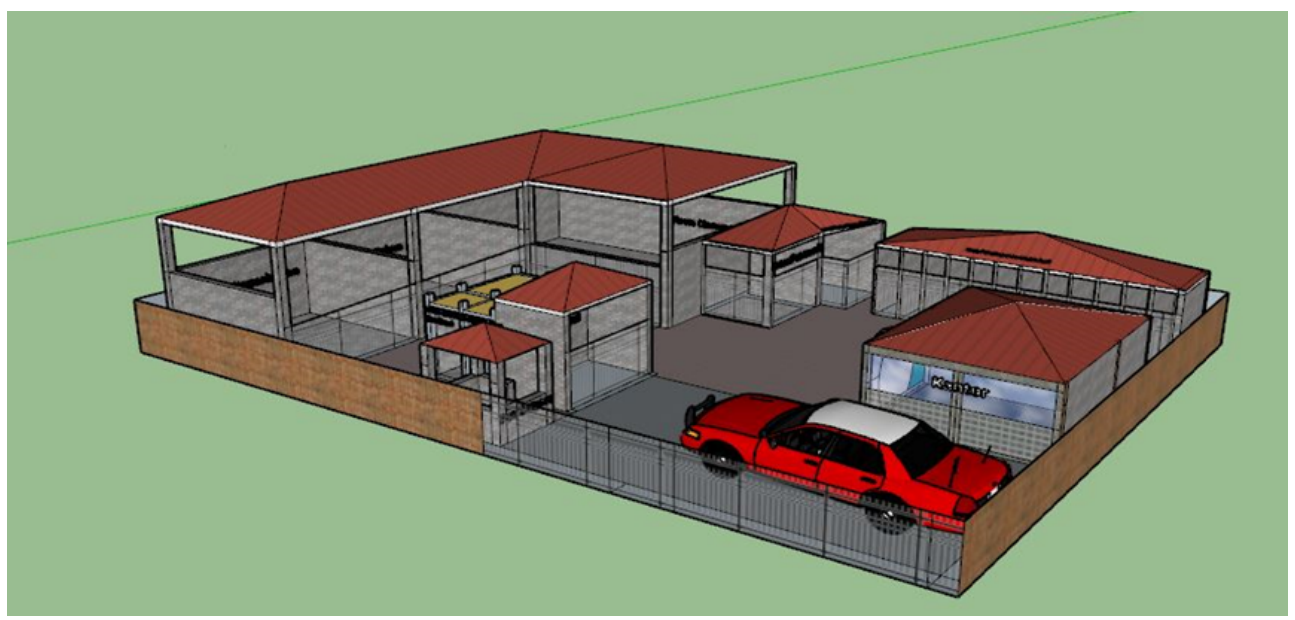

Fig. 5 Front View of TPS 3R Design

\subsection{Planning of Residual (Disposable Waste) Transportation}

Planning of residual transport using Manual Stationary Container System (SCS), where waste dump from TPS 3R is transported using dump truck with capacity of $8 \mathrm{~m}^{3}$ to Pasuruhan Landfill in Muntilan. SCS system is available in the Minister of Public Works Regulation No 03 Year 2013 of the second shift.

The total volume of the residue is 6333.82 Liter or $6.3 \mathrm{~m}^{3}$ per day, then transported to the TPA is done once a day using a dump truck with a capacity of $8 \mathrm{~m}^{3}$ in the morning.

\section{Conclusion}

Based on the amount of waste per capita in the religious tourism object of Gunungpring tomb park is $0.14 \mathrm{~kg} /$ person / day with an average volume of 0.32 Liter / person / day. According to recyclability, the waste composition in Gunungpring tomb park are $49.84 \%$ recyclable, $29.53 \%$ compostable, and $20.63 \%$ of residue discharged to Pasuruhan landfill in Muntilan sub district. In the future, the evaluation of waste management that runs in the religious tourism object of Gunungpring tomb park is necessary obtained. Then, study the role of tourists who visit the religious tourism object of Gunungpring tomb park in waste management should be conducted to identified the behaviour of the tourist and to change it. After that, the role of the management of religious tourism object of Gunungpring tomb park about the rules of littering on the location of tourist parking must be arranged and finally the study of Zero Waste Index would be interesting to know the benefit for environment while solid waste was managed properly.

This study is part of an on-going research project studying strategies for designing the new technology at the solid waste processing facility. The authors would like to give a special thanks to Mr. Dr Ing. Widodo Brontowiyono, dean of FCEP UII and the chief of R \& D Center for Implementation of Settlement Technology, Ministry Public Works and Human Settlements Republic of Indonesia that has supported the study. 


\section{Reference}

1. Badan Pusat Statistik. Magelang dalam Angka (2017)

2. L. Piippo, A. Juntunena, A. Kurppab, E. Pongrácza, Res., Consrv. \& Recyc. J. The use of bio-waste to revegetate eroded land areas in Ylläs,Northern Finland: Toward a zero waste perspective of tourism in the Finnish Lapland. 93, 9-22 (2014)

3. J. Malinauskaite, H. Jouhara, D. Czajczynska, P. Stanchev, E. Katsou, J. Energy. Municipal solid waste management and waste-to-energy in the context of a circular economy and energy recycling in Europe. 141, 2013-2044 (2017)

4. R. Chifari, S.L. Piano, S. Matsumoto, T. Tasaki, Waste Manag. J. Does recyclable separation reduce the cost of municipal waste management in Japan?. 60, 32-41 (2017)

5. S. Lebersorger, and P. Beigl, Waste Manag. J. Municipal solid waste generation in municipalities: Quantifying impacts of household structure, commercial waste and domestic fuel. 31, 1907-1915 (2011)

6. D. Grazhdani, Waste Manag. J. Assessing the variables affecting on the rate of solid waste generation and recycling: An empirical analysis in Prespa Park. 48, 3-13 (2016).

7. X. Jia, S. Wang, Z. Li, F. Wang, R. Raymond, R.R. Tan, Y. Qian, J. of Clnr. Prdct. Pinch analysis of GHG mitigation strategies for municipal solid waste management: A case study on Qingdao City. 174, 933-944 (2018)

8. S.P. Gundupalli, S. Hait, A. Thakur, Wste Manag. J. Multi-material classification of dry recyclables from municipal solid waste based on thermal imaging. 70, 13-21 (2017)

9. N. Singh, D. Cranageb, S. Leeb, Intr. J. Hsptal. Manag. Green strategies for hotels: Estimation of recycling benefits. 43, 13-22 (2014)

10. D. Moya, C. Aldas, G. Lópeza, P. Kaparaju, 9th International Conference on Sustainability in Energy and Buildings. Municipal solid waste as a valuable renewable energy resource: a worldwide opportunity of energy recovery by using Waste-ToEnergy Technologies. SEB-17 (2017)

11. X. Bing, M. Jacqueline. J.M. Bloemhof, T.R.P. Ramos, A.P. Barbosa-Povoa, C.Y. Chee Yew Wong, G.A.J. Vorst. Wste Manag. J. Research challenges in municipal solid waste logistics management. 48, 584-592 (2016)

12. J.M.B.M. Moura, I.G. Pinheiro, J.L. Carmo, Wste Manag.J. Gravimetric composition of the rejects coming from the segregation process of the municipal recyclable wastes. $\mathbf{7 4}$, 98-109 (2018)

13. A. Mesjasz-Lech, Procedia - Social and Behavioral Sciences J. Municipal waste management in context of sustainable urban development. 151, 244 - 256 (2014)

14. T.V. Ramachandraa, H.A. Bharatha, G. Kulkarnia, S.S. Han, Renew. \& Sust. Enrg. Rviw. J. Municipal solid waste: Generation, composition and GHG emissions in Bangalore, India. 82, 1122-1136 (2018)

15. A. Rafiee, E. Gordi, W. Lu, Y. Miyata, H. Shabani, S. Mortezazadeh, M. Hoseini, J. Clnr. Prod. The impact of various festivals and events on recycling potential of municipal solid waste in Tehran, Iran. 183, 77-86 (2018)

16. T.R. Ayodele, M.A. Alao, A.S.O. Ogunjuyigbe, Res, Consrv. \& Recyc. J. Recyclable resources from municipal solid waste: Assessment of its energy, economic and environmental benefits in Nigeria. 134, 165-173 (2018) 